\title{
A unique rod lens/video system designed to observe flow conditions in emergency core coolant loops of pressurized water reactors
}

Gary W. Carter

December 28, 1979 


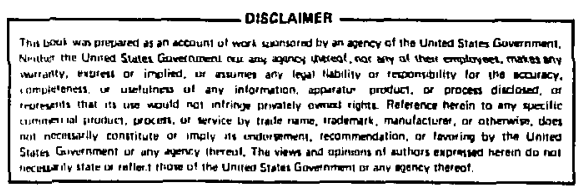

\title{
A unique rod lens/video system designed to observe flow conditions in emergency core coolant loops of pressurized water reactors
}

\author{
Gary W. Carter
}

Manuscript date: December 28, 1979 


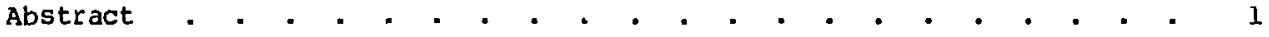

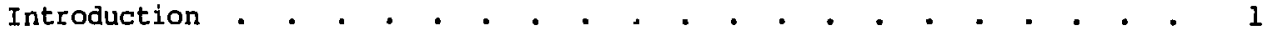

Spool Piece Measurement System . . . . . . . . . . . . 2

KWU PKL Test Facility • . • • • . • • • . • . . . . 3

Wyle Laboratories Experimental Test Facility . • . • . . . . 5

PKL Video Imaging Equipment . . . . . • . • • • • . • . . 6

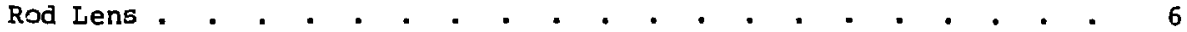

Video Camera (CCTV) . . . . . . . . . . . . . . . . . . 9

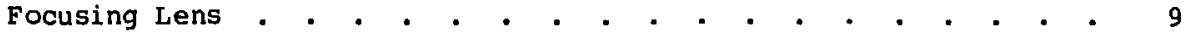

Camera Support Fixture . . . . . . . . . . . . . . . 10

Video Recorder/Monitor . . . . . . . . . . . . . . . 11

Environmental protection . . . . . . . . . . . . . . Il

PKL Spool piece Testing . . . . . . . . . . . . . . . . 11

Photographic Examples . . . . . . . . . . . . . . . 12

Rod Lens/Video System Analysis . • • • • • • • • . • . • . 17

Visualization Methods . . . . . . . . . . . . . . . 17

Temperature Compensation . . . . . . • . • . . . . . 18

Acknowledgments . • . . . . . . . • . . . • . . . . . 20

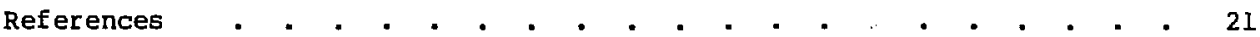

Appendix: Video Log of PKL Instrumented Spool

piece Tests 


\section{A UNIQUE ROD LENS/VIDEO SYSTEM DESIGNED TO OBSERVE \\ FLOW CONDITIONS IN EMERGENCY CORE COOLANT LOOPS \\ OF PRESSURI ZED WA'PER REACTORS}

ABSTRACT

This report describes techniques and equipment used for video recordings of the single- and two-phase fluid flow tests conducted with the PKL Spool Piece Measurement System designed by Lawrence Livermore Laboratory and E.G.\& G. Inc. The instrumented spool piece provides valuable information on what would happen in pressurized water reactor emergency coolant loops should an accident or rupture result in loss of fluid. Field testing of the $80.8-\mathrm{mm}$ and $113.0-\mathrm{mm}$ internal diameter spool pieces was conducted at the Wyle Laboratories Experimental Test Facility in Norco, CA. The video recordings of the various flow parameters were made between February and April 1979. The complete closedcircuit television video system, including rod lens, light supply, and associated spool mounting fixtures, is discussed in detail. Photographic examples of test flows taken during actual spool piece system operation are shown.

\section{INTRODUCTION}

The sophisticated Spool Piece Measurement System is a key portion of a major reactor technology research program being conducted by the German Primarkreislauf (PKL) Test Facility by Kraftwerk Union (KWU) in Erlangen, West Germany. This system was constructed to perform and evaluate loss-of-coolant experiment (LOCE) reflood tests for the pressurized water reactor (PWR). The Lawrence Livermore Laboratory (LLL) and E.G.\& G., Inc., San Ramon Operations, were responsible for design, development, and testing of the four spool pieces, including the associated computerized Data Acquisition System (DAS). A separate report detailing spool design, instrumentation, and test results is given in LLL formal report UCRL-52855. ${ }^{1}$ prototype testing also included the use of the LLL Rod Lens/Video Imaging System (Fig. 1) to view and record dynamic fluid flows produced during spool calibration and instrumentation testing. 


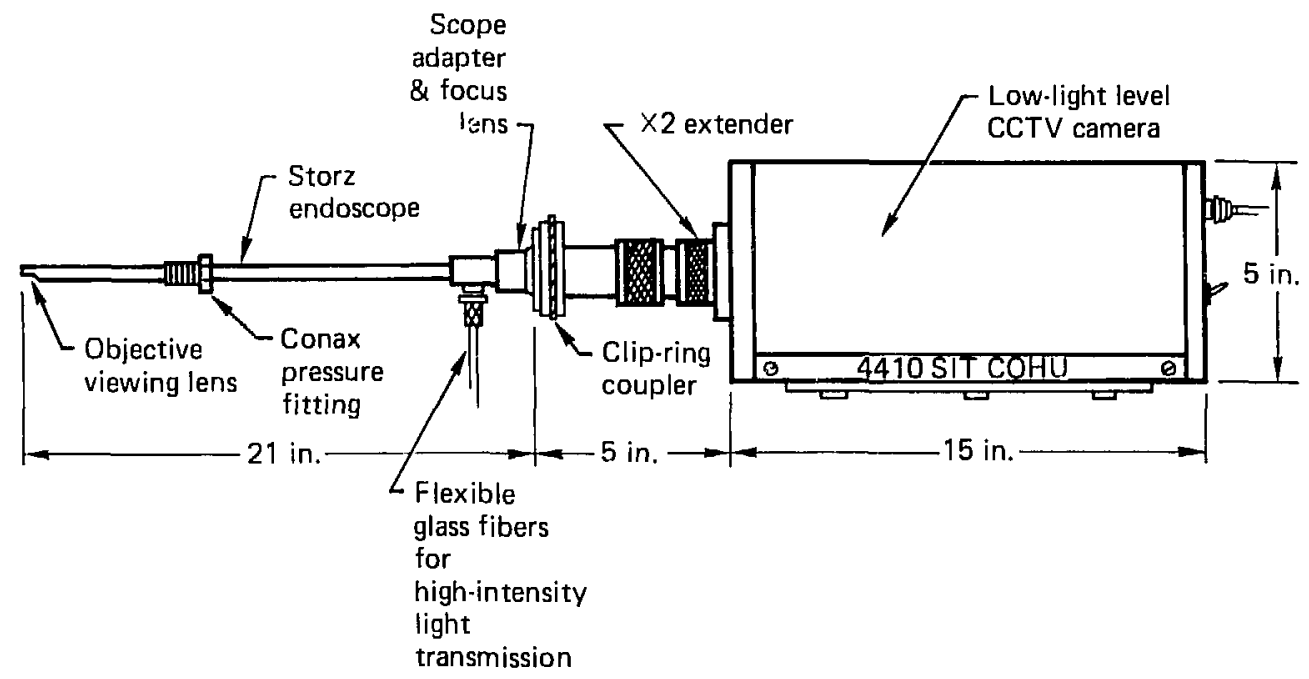

EIG. 1. Viev nF a typical Rod Optir Video System.

This report addresses specifically the rod lens/video system used during PKL spool piece testing and evaluation.

The instrumented spool pieces were developed and tested for the U.S. Nuclear Regulatory Commission (NRC), Division of Reactor Safety Research, under the 3-D Techrival Support and Instrumentation Program in conjunction with the goverrments of West Germany and Japan working on a joint cooperative Reactor Safety Research Program.

SPOOL PIECE MEASUREMENT SYSTEM

Four instrumented spool pieces (three of $80.8-m m$ diam, and one of 113.0-mm Aiam) were fielded; they were designed to measure single- and two-nhase fluid flow conditions during reflood tests. The instrumentation package associated with each spool piece resolves: temperature measurements of the wall, fluid, and steam; pressure niez urements (absolute and differential); fluid velocity; momentum $\bar{l} l u x ;$ and flı $d$ density. The video-coupled rod lens system added another dimension to tr spool piece instrumentation; namely correlation and verification by visual real-time in situ viewing of events occurring within the pipe section as shown by the spocl system's instrumentation sensors. It should be noted that the use of the video/rod lens system 


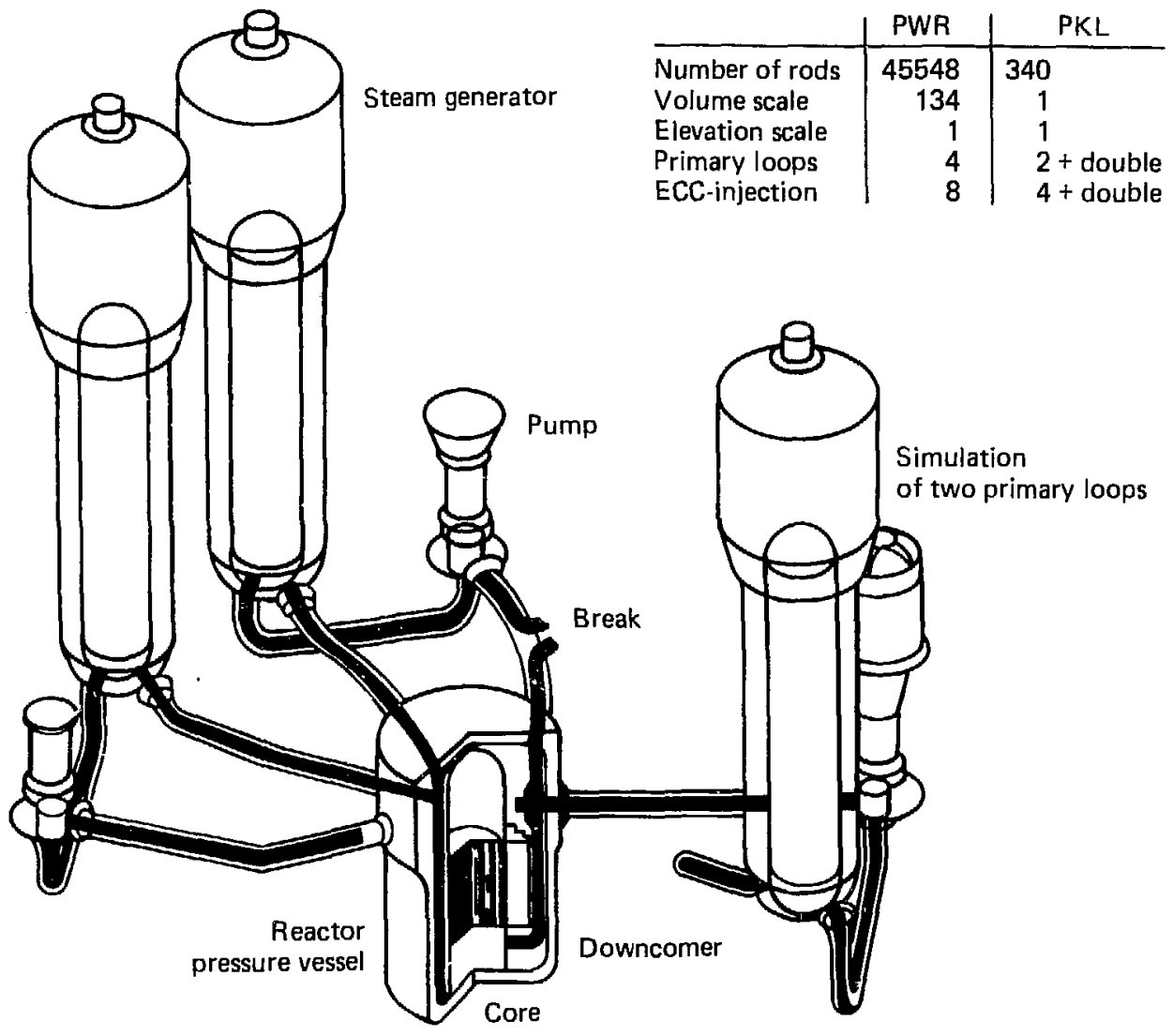

FIG. 2. PKT, simuletinn of a four-loop pressurized water reactor (PWR).

was intonded not as a possible rtulacement for the various spool-piece instru-mentation sensors, but rather to v:sually enharce and supplement them, thereby establishing confidence in sensor integrity and system reliability.

During field testing of the spool-pieces, a tetal of 28 different test sequences were recorded by the video/rod lens system. These included water cailibrations, annular mist, slug flow, superheated steam, and wave motion.

KWU PKL TEST FACILITY

A model of the Primarkreislauf (PKL) Test Facility by Kraftwerk Union (KWU) in Erlangen, West Germany, is shown in Fig. 2. The reflood test simulates conditions that could be encountered should breaks develop in either hot 


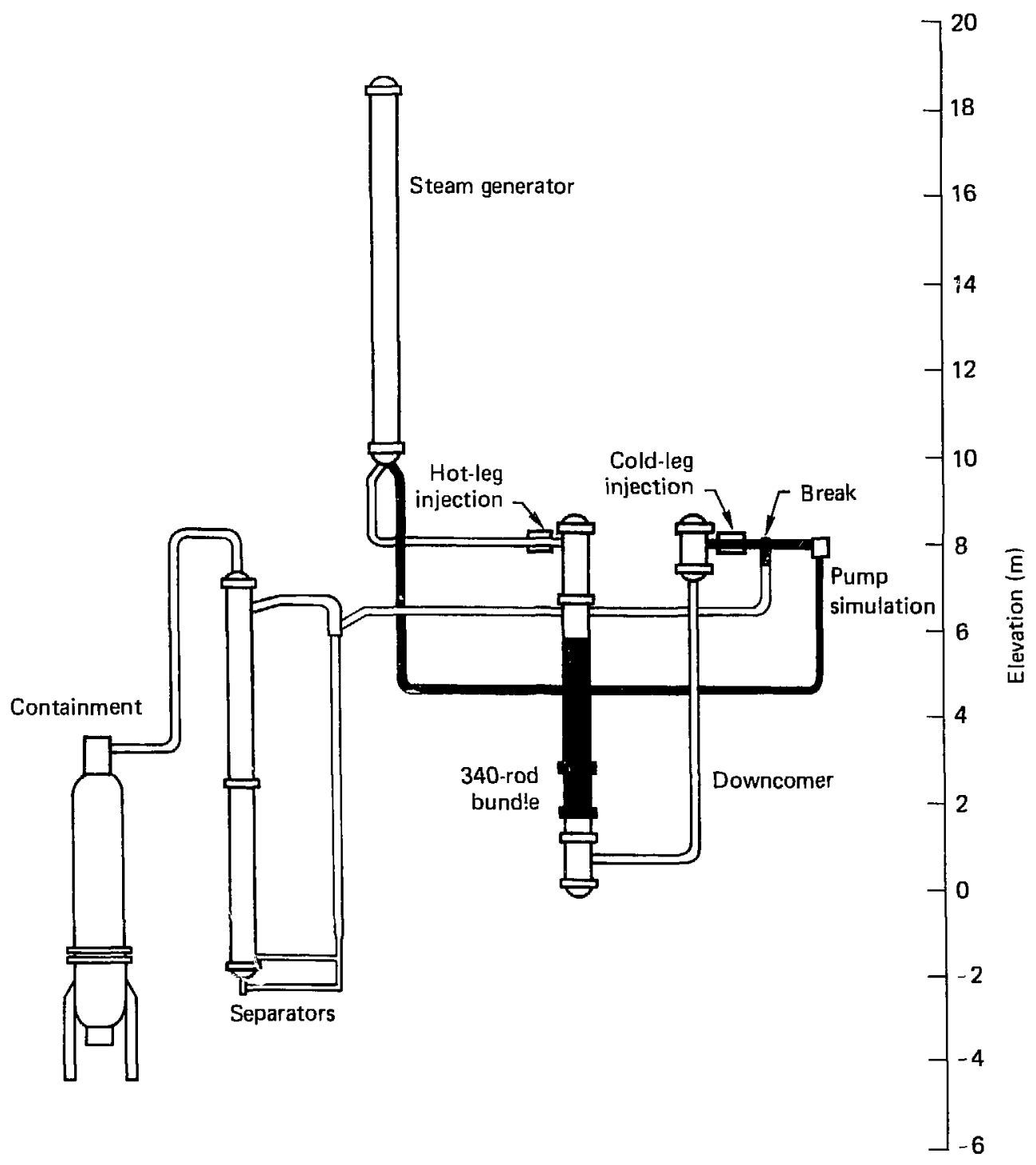

FIG. 3. Cold-leg break simulation in the PKL reactor.

or cold coolant loops of a pressurized water reactor (PWR). Figure 3 shows a break in one of the cold coolant loops. Relative locations of the four PKL: instrumented spool pieces are shown in Fig. 4. 


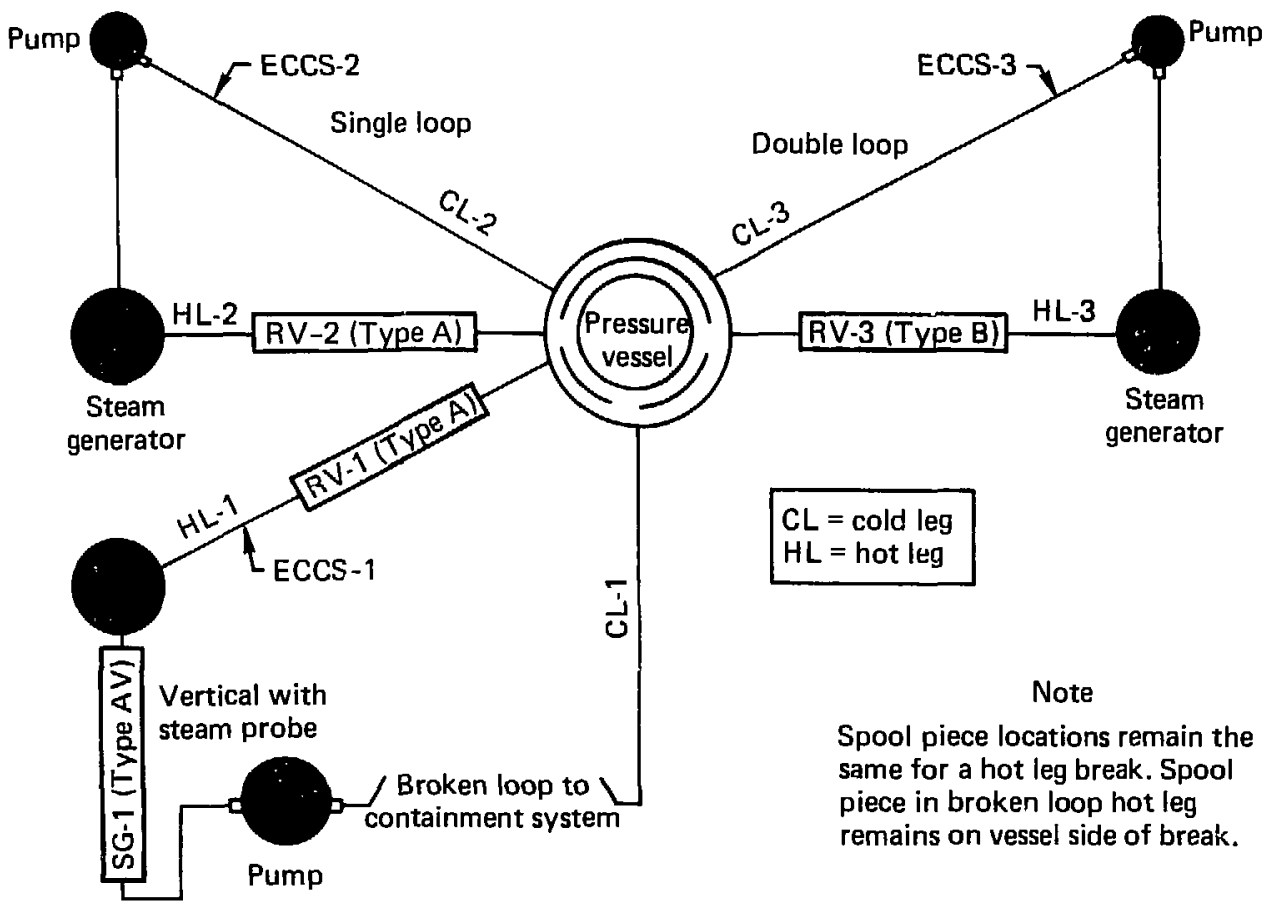

FIG. 4. PKL Reflood Test Facility schematic (cold-leg break).

WYLE LABORATORIES EXPERIMENTAL TEST FACILITY

The Wyle test facility located in Norco, California was the site chosen for PKL instrumented spool piece calibration and testing (Fig. 5). Figure 6 shows the flow diagram for the two-phase flow tests and location of the PRL spool piece test section.

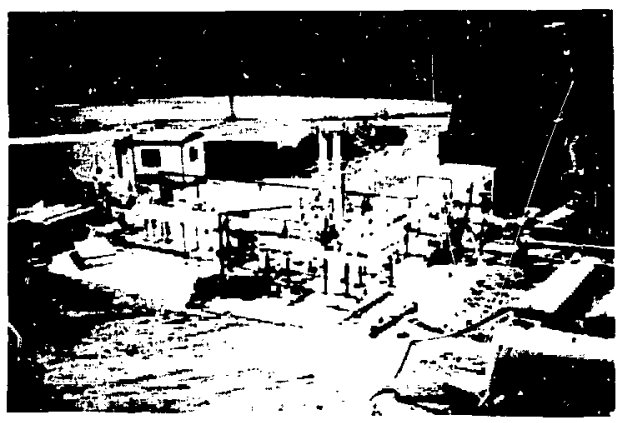

FIG. 5. Wyle experimental facility, Norco, CA site of the single- and two-phase flow testing program for PKL spool pieces. 


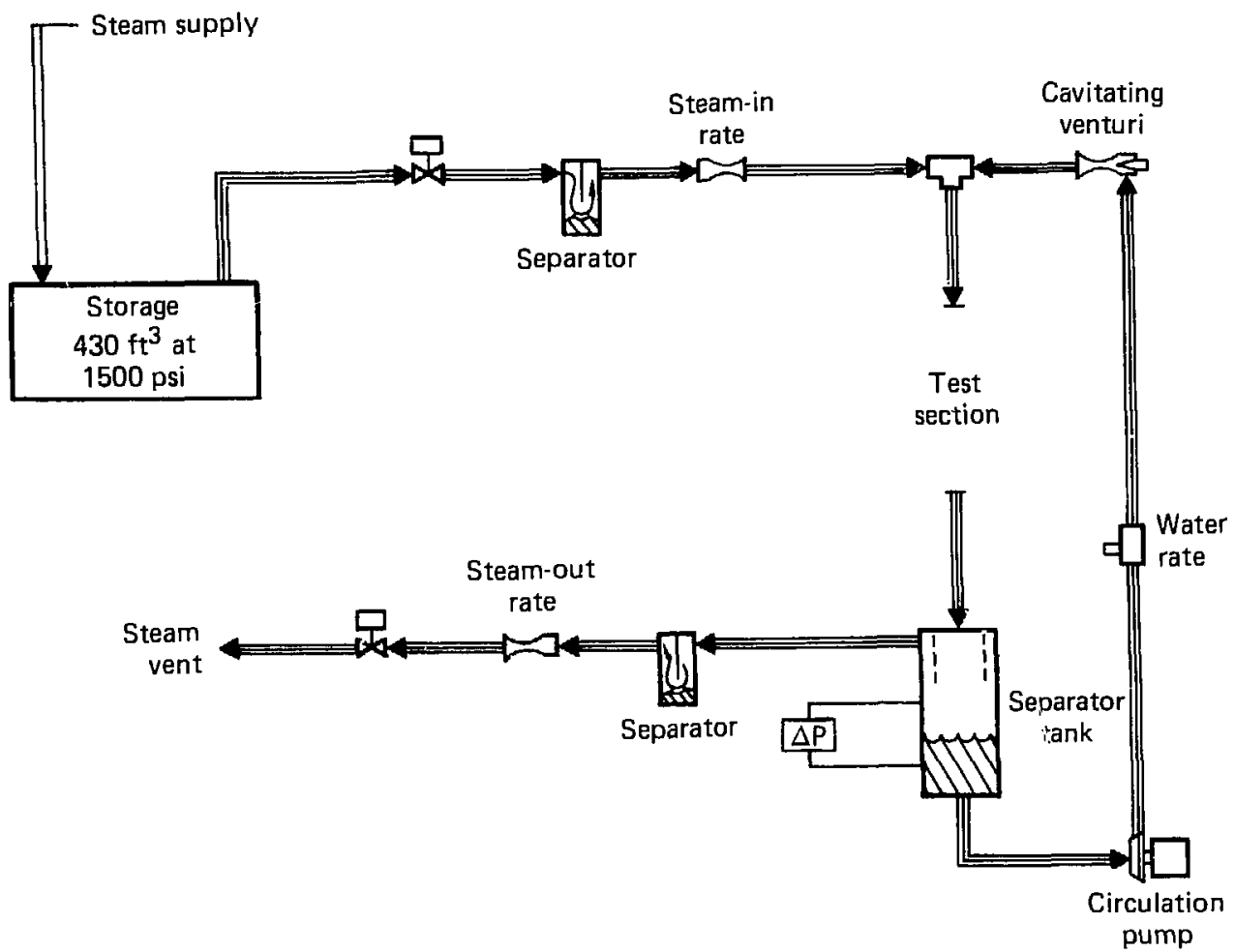

FTG. 5. Throphasp test farility Elow diagram.

PKL VIDEO IMAGING EQUIPMENT

ROD LENS

The rod lens selected for the PKL instrumented Spool Fiece Testing Program is a commercially available 0.5-m-long cylindrical optical system with a cross-section diameter of approximately $5 \mathrm{~mm}$ (Fig. 7). The rod lenses, which are manufactured by storz Company in West Germany, were originally designed and developed as a medical instrument intended primarily for internal photography, hence designated "endoscope" by the manufacturer in preference to the medical profession. Since our particular scientific endeavors employing "endoscopes" lean more toward industrial uses, we prefer to characterize the intelligence gathering optic system as a rod lens.

The basic construction of the Storz entoccope/rod lers consists of a series of solid imaging lenses surrounded by a built-in bundle of lighttransmitting glass fibers (Fig. 8). One of the unique features of the rod 


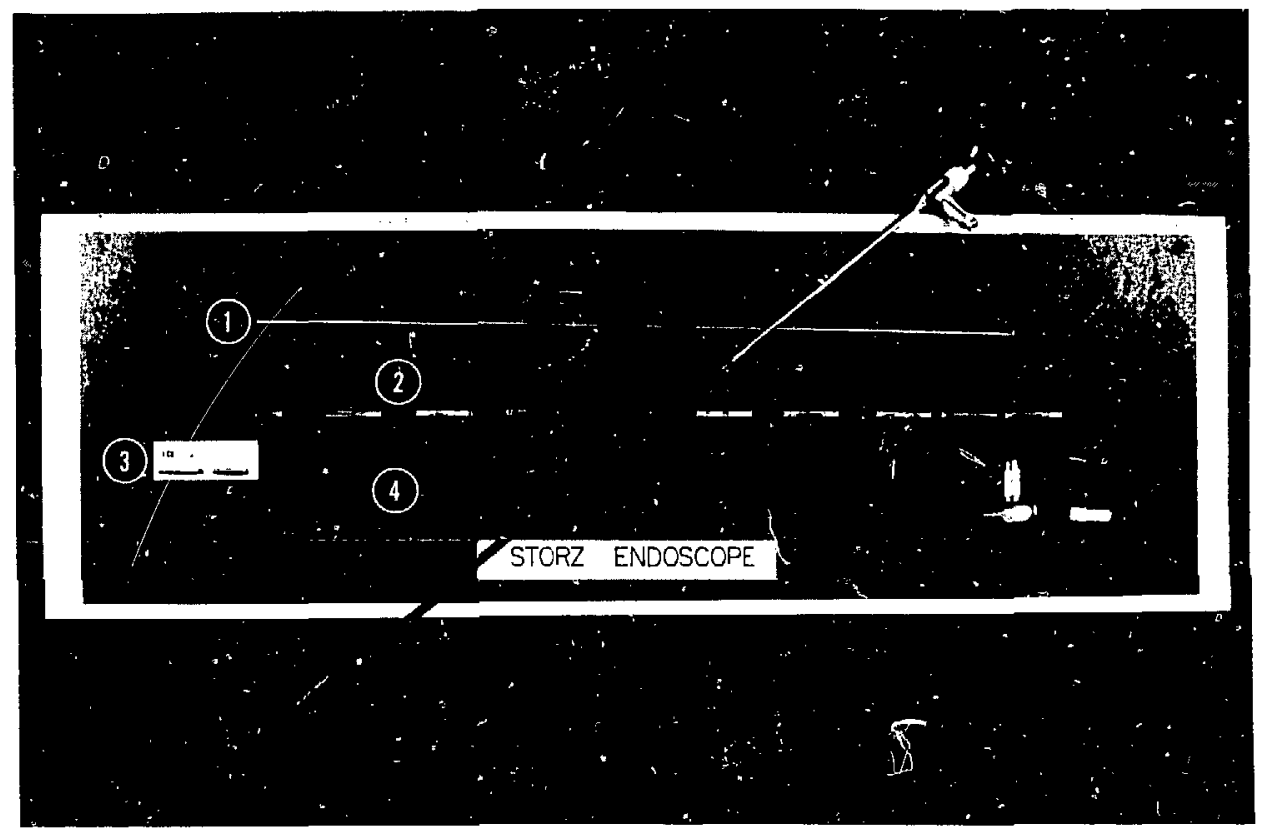

FIG. 7. Rod lens configuration: (1) lens tube, (2) rod lenses and separators, (3) objective lens assembly, (4) outside tubing (containing light fibers) and eyepiece.

lens endoscopic system is demonstrated by the method devised to transmit high intensity light for object illumination. Supplying internal illumination by the rod lens system, particularly in regard to the spool pieces, is in part accomplished by the use of a quartz halogen light source whose output is focused and transmitted through a cablelike, flexible fiberoptic to the rod lens unit. Light arriving at the rod lens unit through the fiberoptic cable, is in turn transmitted through a bundle of minute glass sibers that fill the annuius between the rod lenses and an external structuraily supporting length of metal tubing. In general, both the input light fibers and output lenses are integral parts of the ieflected light transmission systein. Thus, illumination which is transmitzed to the object through the fiberoptics is reflected and returned by the series of solid lenses.

Several other manufacturers of endoscopes possessing similar qualities are also comercially available such as the Nikon Endoscopic System ${ }^{2}$ produced by Nikon camera, and the Olympus-Selfoc Systeim employing a unique lightretention, self-focusing lens assembly $y^{3-8}$ developed by Olympus camera. 


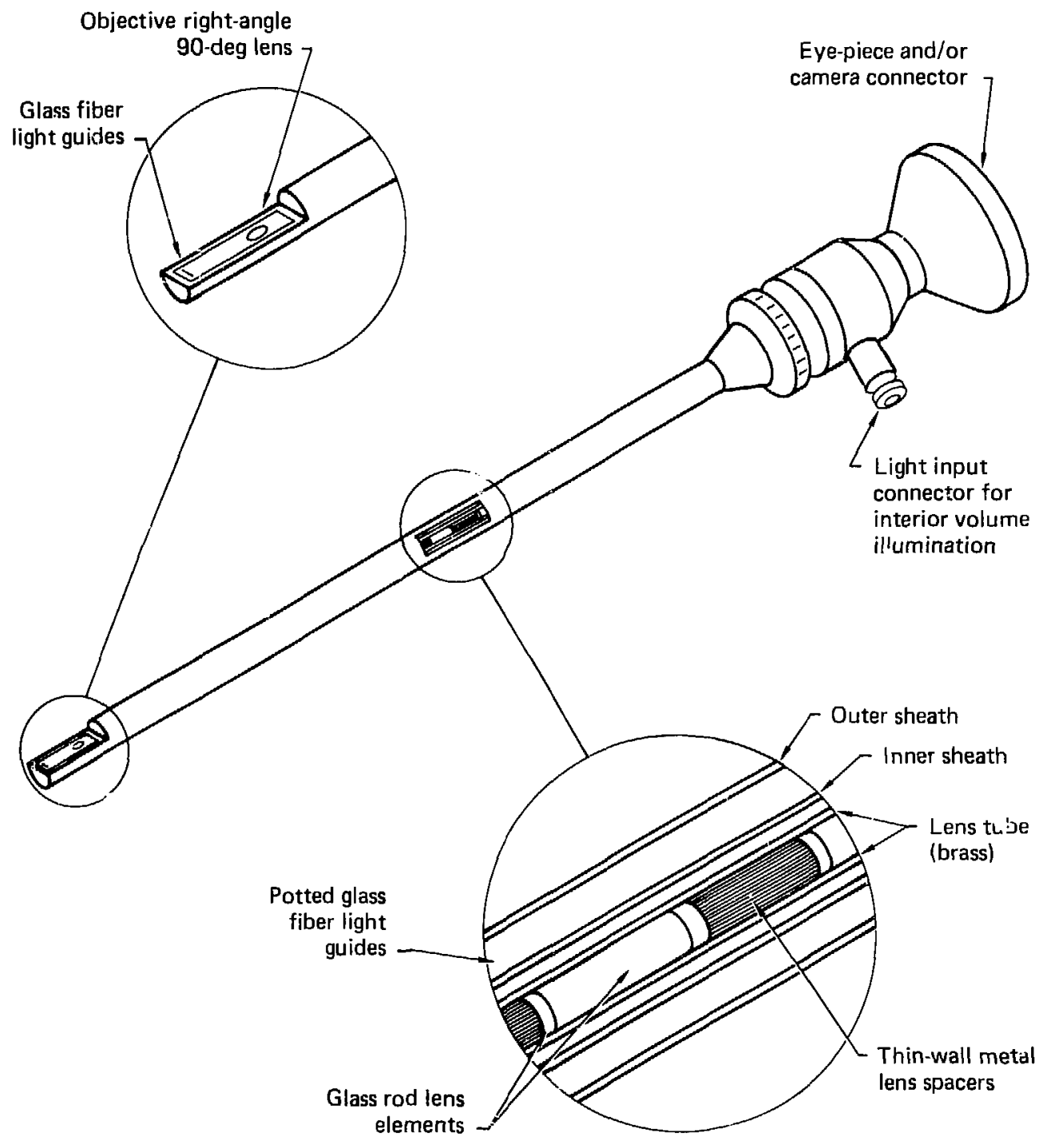

FIG. 8. Storz ror lens optin svstem.

The Storz rod lens assembly has been used in previous experiments ${ }^{9-12}$ conducted at LLL and has shown no adverse effects to prolonged environmental test temperatures (steam/water) of $100^{\circ} \mathrm{C}$ and pressures approaching 2500 psia $(17.5 \mathrm{MP}$ ) .

Although rod lenses can be purchased with various viewing angles 10,30 , 60,90 , and $120 \mathrm{deg}$ ), we selected the 90-deg angle which would allow us to 
direct the view up or down the axis of the spool piece. Rotation of the lens unit (0 to $360 \mathrm{deg}$ ) allows 360-deg observation. It can also be moved vertically to examine underwater conditions, subsurface, above surface, and vapor flow characteristics. The rod lens could also, due to modifications incorporated into the design of the spool pieces, be inserted into the spool either vertically ( $0 \mathrm{deg})$ or horizontally $(90 \mathrm{deg})$ through modified Conax pressure fittings. Teflon seals were used in the Conax fittings, which allowed lens depth-of-insertion and rotation adjustments even under pressurized test conditions.

VIDEO CAMERA (CCTV)

Although the rod lens is a vast improvement over conventional borescopes due to its low transmitted light loss and increased depth-of-field viewing, it still does not transmit sufficient light to record dynamic two-phase flow events using standard Vidicon CCTV cameras. Therefore, we coupled the rod lens to a Cohu low-light level $\mathrm{B} / \mathrm{W}$ television camera with a light intensity gain of $40,000: 1$. This increased sensitivity is achieved by the use of a silicon-intensified target (SIT) 250 times more sensitive than the standard Vidicon camera. Typical horizontal resolution of the SIT is 700 lines with image tube sensitivity of approximately $2 \times 1 \mathrm{u}^{-4}$ lumens/ft ${ }^{2}$ (fc). The camera also incorporates an automatic gain control with automatic bandwidth reduction at low light levels which compensates for bright/dark images, thereby eliminating the need to adjust video levels during rapid brightness changes occurring in dynamic two-phase flow events. This automatic video level adjustment also acts to protect the SIT tube from damage (burns) due to sudden and intensely bright reflections.

FOCUSING LENS

Coupling the rod lens to the video camera is achieved by using a speciaiizer adapter which screws directly into the camera Eaceplate C-mount. The rod lens is secured to the adapter by a spring-loaded clip-ring which allows 360-deg rotation of the rod lens without removal from the camera. A variable focusing lens is an integral component of the adapter and can be used to focus on objects as close as 1 mil from the objective viewing lens, or change the depth-of-view field to infinity. This is particularly important if one wishes 
to view vapor aroplets at extremely shallow depths of field or increase the viewing angle to include the total system. It should be noted that as you increase the depth-of-field, vapor droplets or bubbles within the field view volume become somewhat transparent or opaque.

\section{CAMERA SUPPORT FIXTURE}

The rod lens used for the PKL flow tests, as previously stated, were 90deg (right-angle viewing) madels which could be rotated 360 deg to provide complete control over the internal view volume. However, rotating the lens also requires rotating the video camera to keep the video image portrayed on the television monitor in proper orientation to the internal spool piece view. The camera support fixtures were designed and fabricatea by LLL and E.G.\& G.'s San Ramon Operations Design Group (Fig. 9). The overall design is similar to that used on the LLL/NRC 1/5-scale Mark I Pressure Suppression Experiment ${ }^{10}$ in that they allow the camera and lens system to rotate together through 360 deg with rod lens spcol penstration adjustable from 0 to $113 \mathrm{~mm}$.

The initial intent during fixture design was merely to support the protruding rod lens, adapter lens, and the low-light level video camera in a rotatable, lightweight structure mounted either directly to the spool piece or supported by an adjustable tripod adjacent to the spool. After studying the design criteria established for the spuol pieces, it was imperative that the video/lens system supporting fixture be an integral part of the spool and, although protruding at a right-angle from the test pipe approximately $100 \mathrm{~cm}$, that it also be able to withstand repeated shock loads in the vertical and horizontal modes of a.t least $10 \mathrm{~g}$ 's. The resulting structure was somewhat

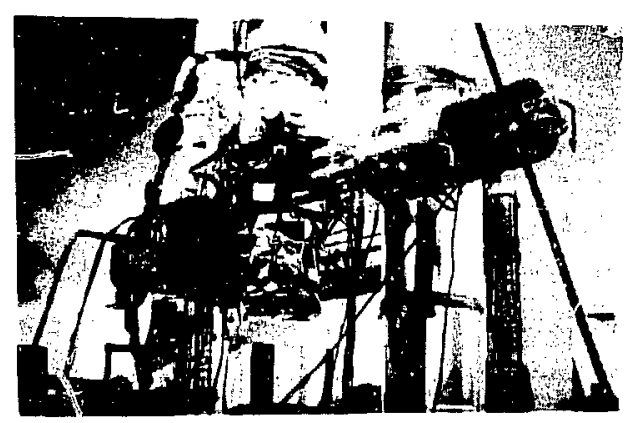

FIG. 9. Rod Lens/Video Imaging System in support fixture mounted on PKL vertical spool piece. 
massive but functional and proved to be extrtmely stable throughout the PRL Spool Piece Test Prcgram.

VIDEO RECORDER/MONITOR

The record/playback system consisted of a Sony EV-320F 1-in., reel-to-reel video recorder and a Sony Unimedia UMT-1203 12-in. B/W/Color video monitor. The Sony reel-to-reel was selected because of its specialized slow-motion, stop-action playback capabilities.

The video monitor and recording equipment were centrally located approximately $50 \mathrm{ft}$ from the Spool-Piece Test pad in an instrurientation trailer provided by Wyle Labs.

ENVIRONMENTAI PROTECTION

Field testing of the spool pieces was cunducted during one of the wettest years ever recorded in the Norco (wyle Test Facility) Area. Further complicating the environmental situation was the complete absence of any protective covering over the spool piece test pad area. Needkess to say, the video cameras, rod lenses, and high-intensity light supplies were not of the hermetically sealed, environmentally protected, waterproof variety. Surprisingly, even though installation and removal of the video system was performed numerous times in heavy rain, no moisture-related video system failures occurred. Long-term protection was afforded by "bagging" the video equipment in clear plastic allowing sufficient volume tn dissipate system-generated heat.

\section{PKL SPOOL PIECE TESTING}

The Rod Lens/Video Imaging System was installed into the PKL $80.8-\mathrm{mm}$ horizontal spool piece on February 16, 1979. The in situ viewing ability of the video coupled rod lens system allowed on-the-syot assessment of real-time internal spool conditions during single and two-phase fluid flow testing. By merely glancing at the displayed internal image of the spcol shown by the CCTV monitor, it became immediately evident if the test cunditions selected were in fact occurring, 1.e., dry pipe, water level, flow movement (forward, still, reverse), wave motion, stean/vapor, sloshing action, bubbles, steam/water mixture, superheat/saturation point, etc. 
FIG. 10. Downstream view of the 80.8-mon horizontal spool (produced by rotating the rod lens $180 \mathrm{deg}$ ) looking directly at the drag screen. The flow meter vanes can clearly be seen behind the center hole of the screen. A thermocouple probe, partially hidden behind the drag screen, is visible in the lower right-hand quadrant. The system is being purged with full steam flow to dry out the spool preparatory to test run. Note evidence of small water flow whish was the rasult of a valve malfunction not suspected nor discovered until seen on the rod lens/video monitor.

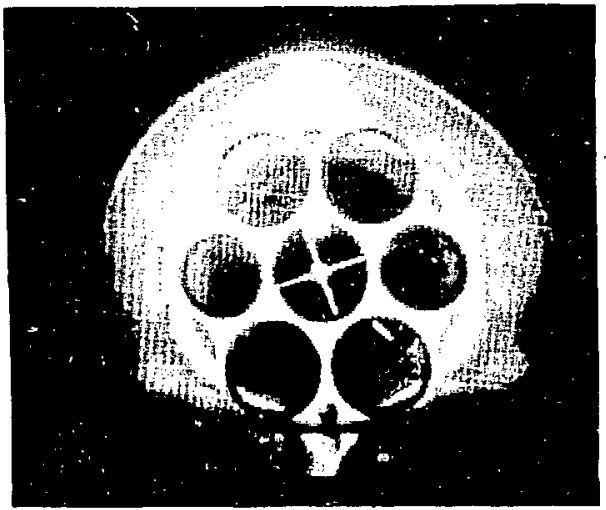

In Eact, the rod lens/video system proved its value in reactor spool piece flow systems when, during the first series of tests, the monitor display showed a significant water flow within the spool when other instrumentation reported a high-temperature, dry pipe condition (Fig. 10). Subsequent investigation revealed a water flow-valve seal malfunction whose failure and results thereof were not detected by spool facility flow system instrumentation. Thus, by visually viewing the internal pipe conditions, the rod lens/video system is capable of immediately cietecting problems o: failures occurring with flow system instrumentation and/or system hardware.

PHOTOGRAPHIC EXAMPLES

Typical photographic exampies of spool piece internal views and test flows are shown in Figs. 10 through 17.

FIG. 11. Photo taken following steam injection with water flow in the 80.8-mm horizontal spool piece (upstream view). Spool temperature is approximately $90^{\circ} \mathrm{C}$. The white line in the center of the spool is an inserted thermocouple probe. The bright dots are moisture droplets condensed along the wall reflecting the rod lens supplied high-intensity light. Note the clarity of machining tool marks and lens depth of field.

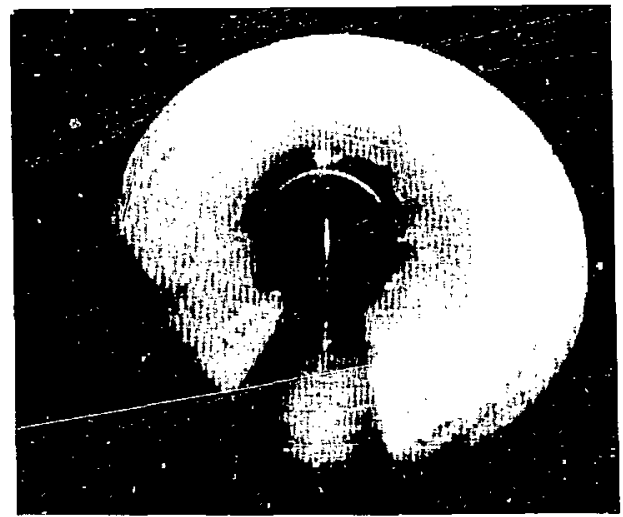




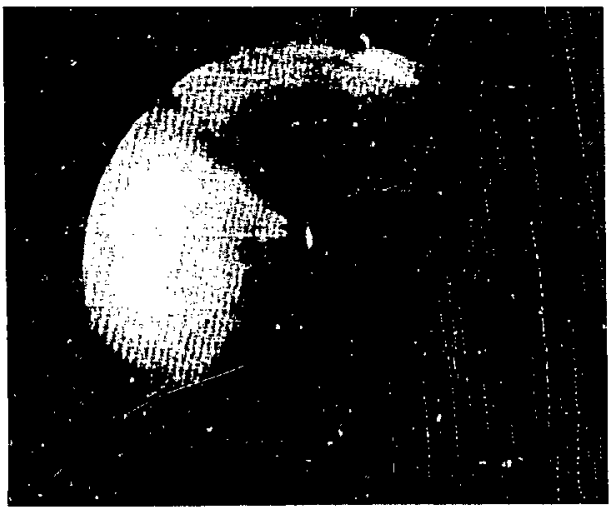

FIG 13. Stratified flow with wave motion created by steam injection. Internal spool temperature is $90^{\circ} \mathrm{C}$ at $60 \mathrm{psi}$.

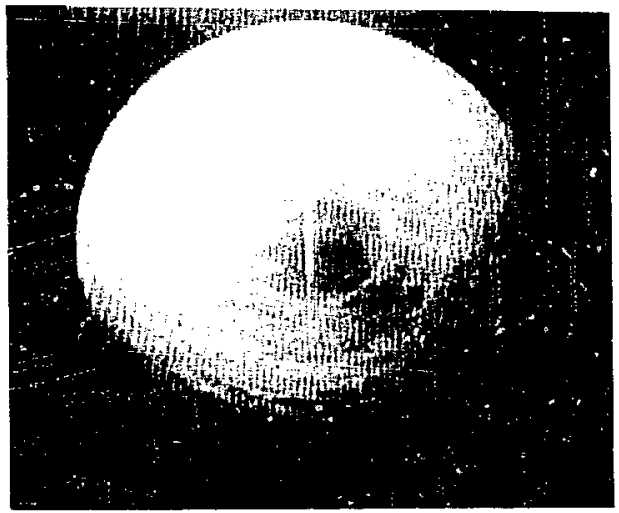

FIG. 15. A closeup of the wall and partial drag screen. Spool temperature is approaching siperheat $\left(164^{\circ} \mathrm{C}\right.$ ) conditions. Notice rirulets of water condensate biing accelerated along the walls toward the drag screen by the steam injection.
FIG. 12. Some Eogging and vapor Flow appear when water is introduced into the $90^{\circ} \mathrm{C}$ spool piece.

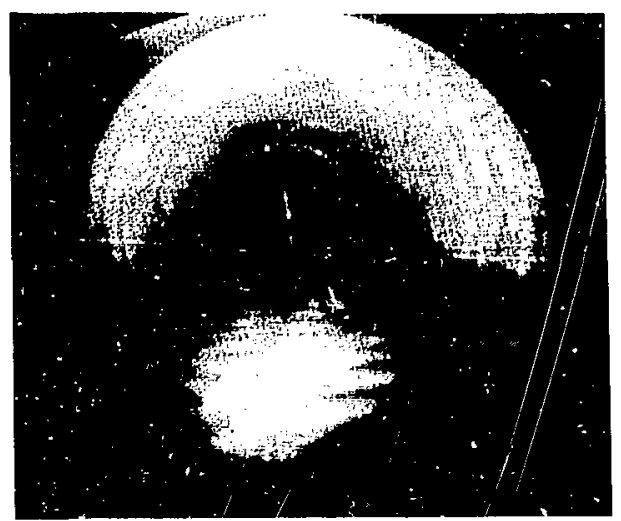

FIG. 14. Full water flow with steam. Swirling, fast moving steam vapor and bubiles can be seen in the upper portion of the spool piece.

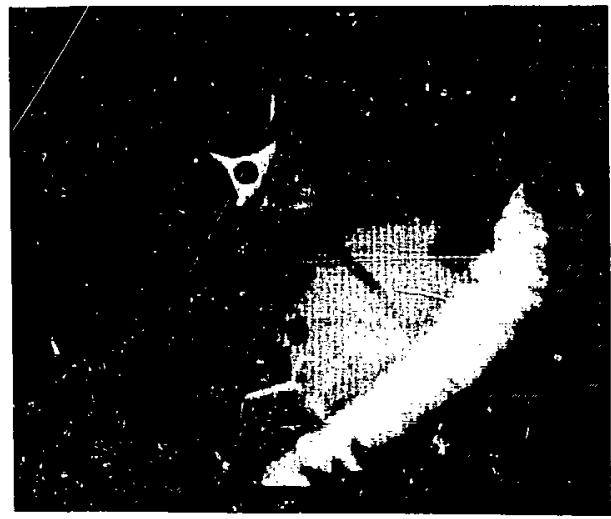


FIG. 16. A view of the drag screen with steam flow during water fill. The fogginess is the result of water vapor and steam injection. The spool system is at atmospheric pressure; temperature is $85^{\circ} \mathrm{C}$.
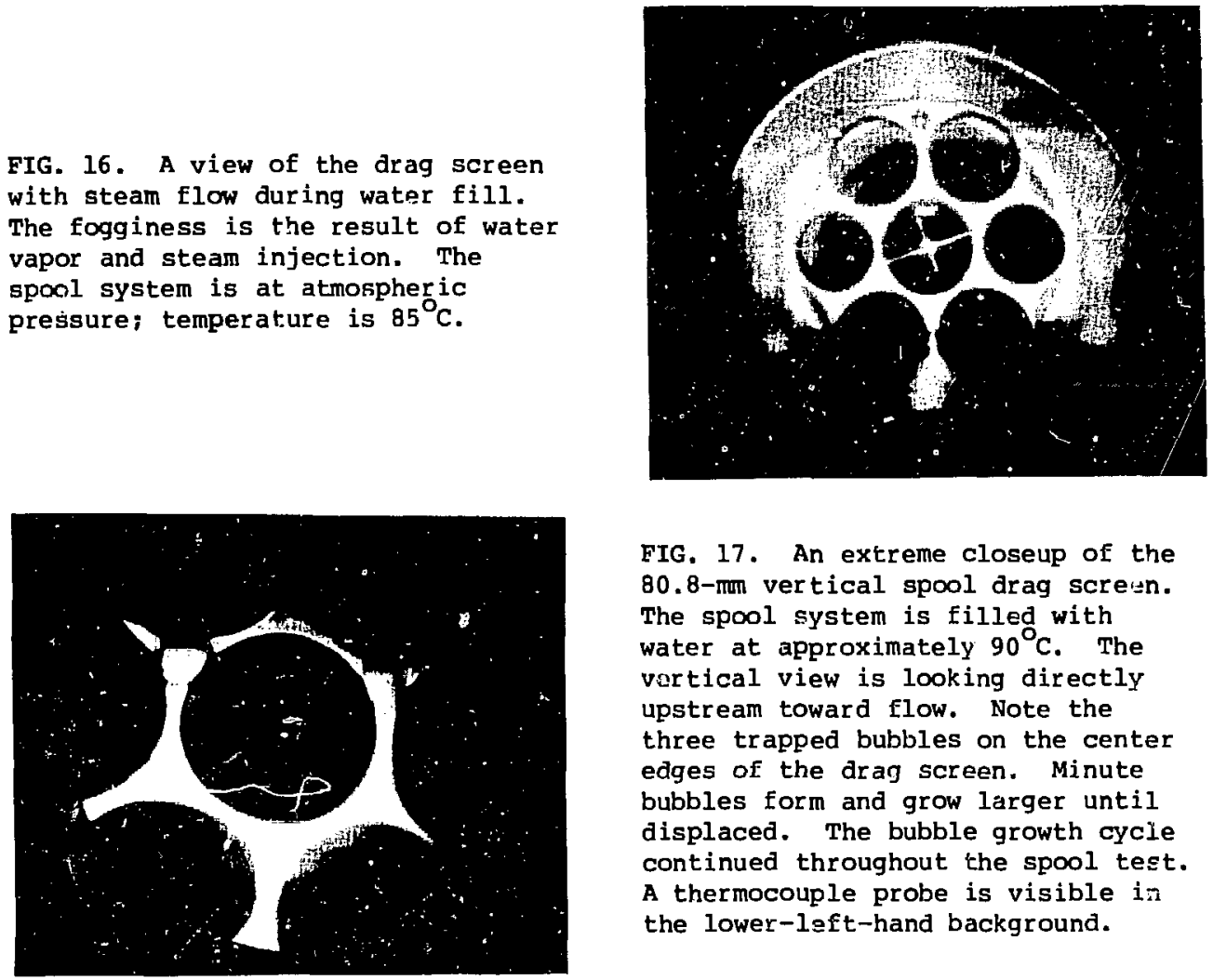

FIG. 17. An extreme closeup of the 80.8-mu vertical spool drag scre The spool system is filled with water at approximately $90^{\circ} \mathrm{C}$. The vertical view is looking directly upstream toward flow. Note the three trapped bubbles on the center edges of the drag screen. Minute bubbles form and grow larger until displaced. The bubble growth cycle continued throughout the spool test. A thermocouple probe is visible in the lower-left-hand background.

No major problems were encountered with the video/lens system during the first series of tests even though the rod lens remained inserted into the spool piece environment from early morning to late night (approximately $12 \mathrm{hr}$ ). Although it was not necessary to view and record a continuous 12 hr of daily testing, the rod lens could not be removed from the spool without complete spool piece test faclity shutdown, cooling, and depressurizing. (Test system pressures ranged from atmospheric to $90 \mathrm{pgia}$ internal temperatures varied from ambient to $170^{\circ} \mathrm{C}$; maximum flow velocities were approximately $60 \mathrm{~m} / \mathrm{s}$.) During the second series of tests (week of 21 February 1979) numerous difficulties plagued the test program which resulted in several long-term soakings of the rod lens at superheat temperatures and pressures (164 degrees C. at 60-90 psia). As spool temperatures, pressures, and flow conditions were cycled, condensation and lens fogging began to interfere with the displayed internal video images. When stabilization of superheat temperatures were 
reached, the lens-portrayed video images were excellent; but when internal spool temperatures or pressures dropped, so did the quality of the rod lens projected images resulting in partjal and distorted views of flow conditions. Distortions and lens fogging continued, sometimes visually clearing followed by rapid degradation until the total view image was darkened and finally lost al together.

Immediately following spool system shutroun, the rod lens was removed and examined. Cursory inspection revealed that aithough sufficient light was being transmitted by the fiberoptics to the object, it was not being returned via the lens assembly to the video coupling/eye-piece unit. Also, the exposed portion of the 90 degree right-angle objective lens potting material showed signs of erosion and pitting caused by the ablative action and high temperature effects of the steam/fluid flow. The suspected cause of failure was possibly due to prolonged exposure to temperature (164 degree $C$ and above) and steam flow inpinging directly upon the 90 degree viewing lens.

At this point it was decided to insert a new rod lens, repeat the test series and during the superheat tests, rotate the lens 180 dagrees thereby viewing downstream and not directly into the stream/fluid flow. This, hopefully would minimize exposed lens damage and avoid subsequent failure of the rod lens unit. Using this method of lens protection, we were able to finish the second series of spool testing with good video results although picture quality near the end of the series was rapidly degrading similar to that experienced with previous rod lens failure.

Complete laboratory disassembly of the units revealed broken and cracked lens segments located slightly below the interface of the Conax pressure fitting. Slight discoloration of the lower section (immersed portion) of the sheath tubing ended midway through the area corresponding with the broken lens segment. Further examination revealed discoloration (brownish) and obvious degradation of the adhesive used to bond individual lens segments. This apparent damage and lens failure was confined nnly to the lower portion of the rod lens assembiy.

The fractured lens segments are believed to be the result of thermal expansion effects caused by extreme temperature gradients.

The protruding portion of the rod lens (above the Conax pressure ficting) was subjected to ambient temperature ranges (10 to $25^{\circ} \mathrm{C}$ ), while lens elements at the interface and below were soaking at spool and fluid flow temperatures sometimes exceeding $170^{\circ} \mathrm{C}$. Microscopic examination of the exposed 
90-deg objective lens potting material also showed slight damage (erosion and pitting) due to effects of ablative action combined with the high temperature of the steam/fluid flow.

It appears that prolonged exposure or immersion in fluid flows at temperatures above $160^{\circ} \mathrm{C}$ results in eventual lens failure with usable lens life (good video/brightness quality) being directly related to the proportional limits of time/temperature.

Replacement of the cracked and discolored adhesive-bonded lens sregments in the lower portion of one rod lens assembly (approximately $10 \mathrm{~cm}$ ) restored the unit to a usable condition and was reserved as a standby lens. The other damaged rod lens unit was deemed not repairable due to extensive fractures and darkening of the exposed 90-deg objective right-angle viewing lens.

The third series of tests on the 113-mn horizontal spool piece (week of March 13, 1979) was modified slightly to allow removal of the rod lens unit during system preheat and testing at superheat temperatures. Rod lens and pipe temperatures were kept below $145^{\circ} \mathrm{C}$; internal pressuzes varied from ambient to 60 psia.

The fourth series of testing commenced during the week of March 27, 1979, using the 80.8-Kun spool piece mounted in the vertical position. Spool and flow temperatures were approximately $145^{\circ} \mathrm{C}$ with internal pipe pressures ranging from 0 to $60 \mathrm{psia.} \mathrm{Midway} \mathrm{through} \mathrm{this} \mathrm{test} \mathrm{sequence,} \mathrm{we} \mathrm{lost} \mathrm{another}$ rod lens. This unit had been used previcusly in test series three. Again, failure of the lens assembly was attributed to long-term temperature effects. The lens was replaced and the test series was completed without further complications.

Typical photographic views as portrayed by the rod lens are shown in Figs. 10 through 17. These internal PKL spool piece images were photographed directly from the television monitor during playback, stop-action analysis and, although of outstanding quality, each actually represents only one-half the available video scan lines necessary to produce a full 525-line television picture. This is due to the design characteristics inherent within most television and recording systems, namely the playback stop-action mode is only capable of freezing a single field, not frame, of video. To form a complete picture or frame of video requires interlacing sequentially one odd and one even raster scan, each consisting of approximately 262 lines and taking 1/60th of a second to record. Thus, we arrive at the conventional U.S. N.T.S.C. (National Television System Committee) television design standard of 30 
Erames/s monitor scan display. Sophisticated electronic disk storage units are available that can store the odd-even fields and, upon demand, display these two fields interlaced to form a stop-action single frame. In our particular case, it is more advantageous to view only a single-field scan of captured dynamic flow conditions because of the rapid movement or velocity of events. Interlacing two sequential fields during stop-action replay results in a blurred image since each field corresponds to events occurring only during that particular $1 / 60$ th of a second.

\author{
ROD LENS/VIDEO SYSTEM ANALYSIS
}

\title{
VISUALIZATION METHODS
}

Ror lenses used in conjunction with closed-circuit television/recording systems to monitor two-phase flow conditions are an extremely valuable addition to conventional spool piece instrumentation. The ability to visually view and substantiate internal dynamic test conditions occurring in a closed volume more than justifies the small additional cost of the rod lens/videocoupled recording system. Of similar importance is the ability to inmediately plavback and analyze the flow sustem by either slow or single-framing methods inherent in video recording devices. Stop-action can be used to perform precise measurements on bubble or droplet size and their associated velocities within the view volume. Further analysis can be achieved by the use of analog or digital electronics enhancement imaging systems, video "window" type detectors for particle/bubble size level determinations, and related electronic video scan systems to differentiate the various flow densities occurring in two-phase flow regimes. For flow syst ems whose velocity approaches or surpasses limitations imposed by the vides scan rate of conventional closedcircuit television systems (30 frames/s), there are commercially available low-light level video cameras which now incorporate a selectable one-tofourfold increase in framing rates $(60,120,180$ and 240 fields per second). 9

One additional method for capturing dynamic flow events not previously discussed in this report is the use of still photography techniques in conjunction with rod lenses (Fig. 18). Good quality black and white photographs can be produced using, for example, 35-mm Kodak Tri-x pan negative film with an ASA film speed of 400 . Very good image resolution can be expected in 
most static scene situations. The exposure time will of course depend upon weighted scene brightness and lens light transmission ability.

The obvious aisadvantages of still photography include film processing time, loss of event correlation timing, relatively long exposures resuliing in blurred images of dynamic events, and, most importantly, the possible loss of the entire photographed test sequence if camera and film development techniques are not letter perfect.

High-speed, fast-framing film cameras are not generally compatible with rod lens systems used in single or two-phase flow environments because of the large amount of light necessary to ensure adequate film exposure when transmitted through small-diameter optic lenses. Comparison studies have been made in relation to still photography versus video systems in both black and white and color experiments. 12

TEMPERATURE COMPENSATION

Although we lost several rod lenses due to spool piece operating temperatures which apparently exceeded the limitations imposed by the optic system design, it appears that modifications could improve rod lens temperatureresistive characteristics to $500^{\circ} \mathrm{c}$ or better. Several methods suggested include an optical protective thermowell, heat-sink cooling jackets similar to heat-pipes, or even possible replacement of the low-melting alloy seals and epoxy lens-mounting materials.

One interesting concept to consider is a spool-mounted thermowell provid-ing protection for the rod lens from extreme temperature and ablative flow conditions until such time as an automated system or operator activates lens insertion into the spool environment for quick-look and video recording. Imnediately following inspection, the rod lens unit could be withdrawn back into the protective confines of the thermowell. This method would increase the usable life of the rod lens by at least several orders of magnitude and not require extensive modification of the basic rod lens for high temperature compensation.

These and other rod lens temperature protective measures were discussed prior to, and during, the PRL spool piece field test but could not be implemented due to program budgetary constraints. 
(a)

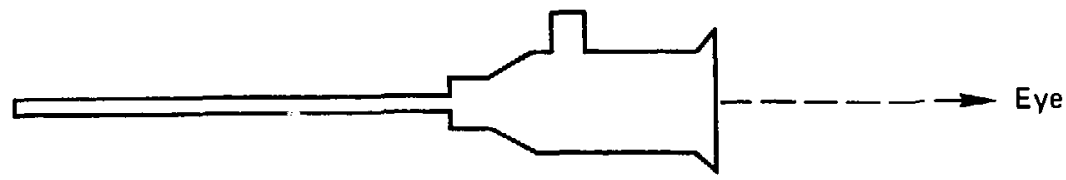

(b)

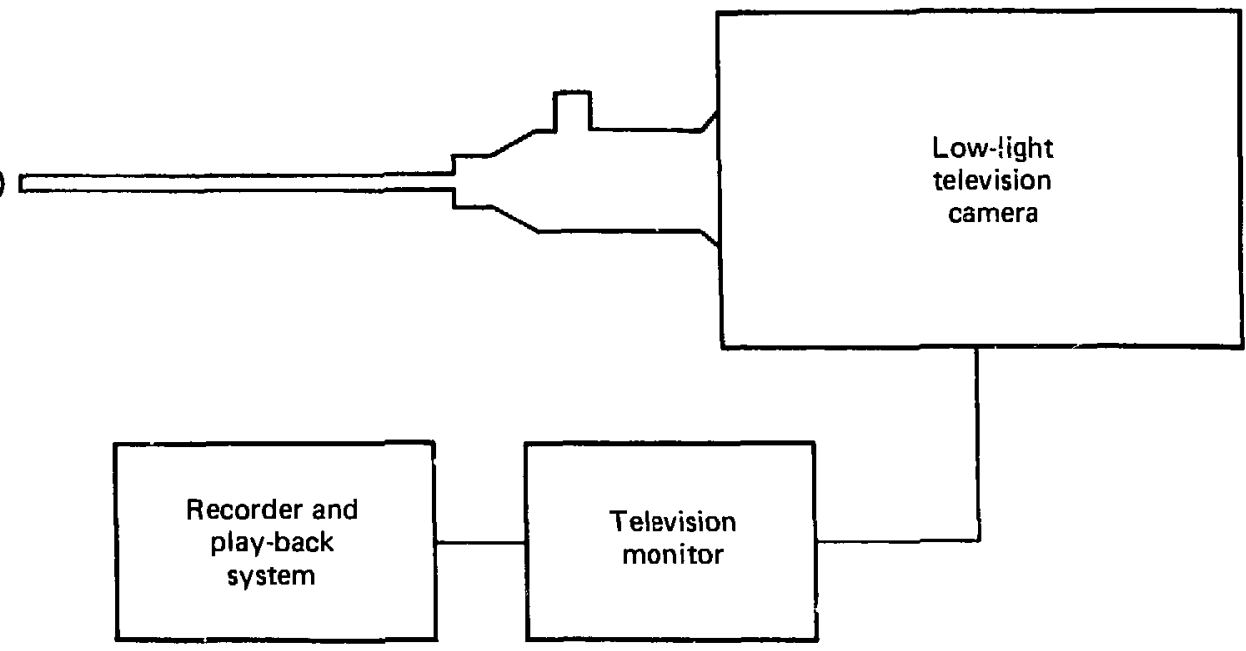

(c)

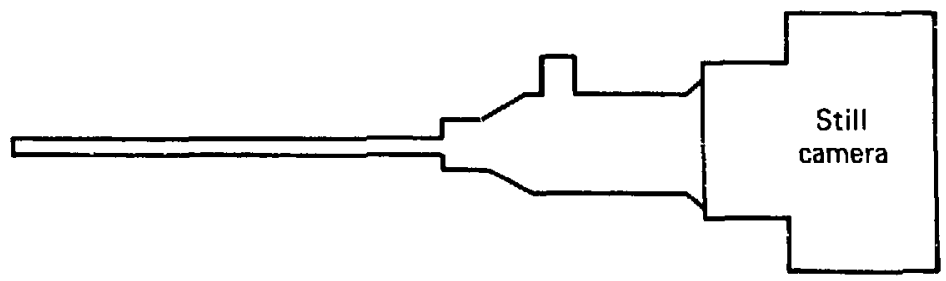

(d)

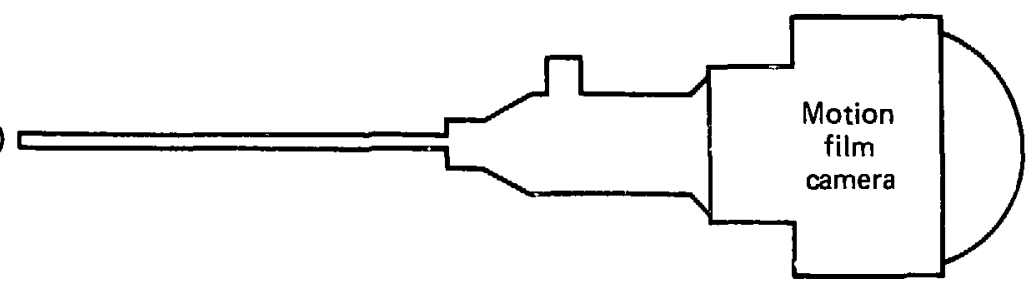

FIG. 18. Visualization methods and image recording: (A) rod optic, light source, human eve; (B) rod optic coupled to low-light video system; (C) rod optic coupled to still camera; (D) rod optic coupled to motion film camera. 


\section{ACKNOWLEDGMENTS}

The author would like to acknowledge and extend appreciation to those individuals who contributed their expertise and support which greatly influenced the successful completion of this work.

- Werner Stein, Thermo Fluid Mechanics Group of Nuclear Test Engineering Division, Lawrence Livermore Laboratory, who implemented and coordinated rod lens system involvement in the PRL Spool-Piece Program.

- Robert Smellie, PKL Spool-Piece Project engineer, E.G.\& G., San Ramon Operations, who provided outstanding technical assistance and support throughout all phases of this endeavor.

- Cnuck Valdez, Drafting Design Leader, E.G.\& G., San Ramon Operations, who helped design and coordinate fabrication of the camera/lens support fixture.

- William Aymer, E.G.\& G, Las Vegas Operations, who supplied mechanical system support throughout the PKL Test. Program.

- Dorin VanLue, Engineering Measurements Section, Materials Engineering Division, Lawrence Livermore Laboratory, who fabricated the specialized Conax pressure-fitting feed-throughs for the rod lenses.

- Ernest Wilson, E.G.\& G., San Ramon Operations, who provided technical electronics support.

- Melvin ratch, E.G.\& G., San Ramon Operations, who assisted with the mechanical and technical aspects of this program. 


\section{REFERENCES}

.1. W. Stein, Measurements, Error Analysis and Calculations of Water and Steam Individual Mass Flow Rates, Velocities, and Related Flow Parameters Obtained from Single-Phase and Two-Phase Prototype Tests of the PKL Instrumented Spool Pieces for the U.S. NRC-RSR 3-D Program, Lawrence Livermore Laboratory, Livermore, CA., Rept. UCRL-52717 (1979).

2. "Nikon Endoscopic System," in Photomethods-Journal of Imaging Technology 22, 11 (1979).

3. H. Kita and T. Uchida, "Light Focusing Glass Fiber and Roid," in Proc. SPIE Seminar on Fiber optics, Dallas, Texas (1970).

4. T. Uchida, M. Furukawa, I. Kitano, K. Koizumi, and H. Matsumura, "Optical Characteristics of a Light Focusing Fiber Guide and Its Applications," in IEEE J. Quantum Electron QE-6 (10) (1970).

5. H. Kita, I. Kitano, T. Uchida, and M. Furukawa, "Light Focusing Glass Fiber and Rods," in J. American Ceramic Society 54, 7 (1971).

6. K. Matsushita and K. Ikeda, "Newly Developed Glass Devices for Image Transmission," in Proc. Soc. Photo-Optical Instrument Engineers 31, 23-25 (1972).

7. E. G. Rawson and R. G. Murray, "Interferometric Measurement of Selfoc Dielectric Constant Coefficients to sixth Order," in IEEE J. Quantum Electronics QE-9 (11), $1114-1118$ (1973).

8. K. Ikeda, K. Nishizawa, and M. Toyama, "Study on the Low Chromatic Aberration of Light-Focusing Glass Rods with a Parabolic Distribution of the Reflective Index," in loth I.C.G. Proc. 6, Kyoto, Japan, pp. 6, 76-81 (1974).

9. D. E. Lord, G. W. Carter, and R. R. Petrini, Flow Observation by Rod Lens and Low-Light Video, Lawrence Livermore Laboratory, Livermore, CA., Rept. UCRL-52324 (1977).

10. D. D. Dixon ani D. E. Lord, Photographic and Video Techniques Used in the 1/5 Scale MKI Pressure Suppression Experiment, Lawrence Livermore Laboratory, Livermore, CA, Rept. UCRL-52367 (1977). 
11. D. E. Lord, G. W. Carter, and R. R. Petrini, Interior Surface Examination by Rod Lenses, R. G. Stone and M. B. Bathgate, Eds., Lawrence Livermore Laboratory, Livermore, CA, Rept. UCRL-50016-77-3 (1977).

12. D. E. Lord, R. R. Petrini, G. W. Carter, and T. D. Clark, optical Inspection of Sma11-Diameter Deep Bores Using Rod Optics with Low-Light Television and Still Photography, Lawrence Livermore Laboratory, Livermore, CA, Rept. UCRL-52431 (1978). 


\section{APPEND I X}

VIDEO LOG OF PKT, INSTRUMENTED SPOOL PIECE TESTS

Video Dat.r rape No. 2 ('mape No. 1 was recorded calihration and system test set-110)

\begin{tabular}{|c|c|c|c|}
\hline Run: & Nn. 35 & Run: & No. 36 \\
\hline Regime: & whater & Regime: & Slug flow, 60 psia \\
\hline D非: & Feh. 15, in79 & Date: & Feb. 16, 1979 \\
\hline I.D.: & $80.8 \mathrm{~mm}$, horizontal & I.D.: & $80.8 \mathrm{~mm}$, horizontal \\
\hline Steam: & 0 & Steam: & $0.154 \mathrm{l} 1 / \mathrm{s}$ \\
\hline ivater: & $219 \mathrm{gpm}$ & Water: & $r .130 \mathrm{lb} / \mathrm{r}$ \\
\hline
\end{tabular}

\begin{tabular}{|c|c|c|c|}
\hline Ru?: & NC. $3 ?$ & Rinn: & No. 38 \\
\hline Rogime: & $\therefore n r_{i a l}$ ar mist, fo peia & Regime: & superheater steam, 60 psia \\
\hline Date: & Fen. ?], 1079 & Date: & Eein. 21,1979 \\
\hline I.D.: & 80.8 min, f.or izontal & I.D.: & $80.8 \mathrm{~mm}$, horizontal \\
\hline steam: & $1.300 \mathrm{th} / \mathrm{s}$ & Steam: & $1.330 \mathrm{lt} / \mathrm{s}$ \\
\hline Water: & ก.:50 1.h/s & water: & 0 \\
\hline
\end{tabular}

Vicen Data Tape No. 3

\begin{tabular}{|c|c|c|c|}
\hline Run: & No. 41 & Run: & Nn. 42 \\
\hline Reqime: & s].ug flom, for paia & Regime: & ennular mist, 60 psie \\
\hline Dete: & Fein. 22, 1979 & Date: & Eo:. 22, 1:70 \\
\hline$\therefore . D_{.}:$ & $80.9 \mathrm{~mm}$, horizontal & $\underline{\underline{I}} . \mathrm{D}_{\text {.: }}$ & $80.8 \mathrm{~mm}$, horizontal \\
\hline Steam: & $0.150 \mathrm{~J} \mathrm{~h} / \mathrm{s}$ & Steam: & $1.3001 \mathrm{~b} / \mathrm{s}$ \\
\hline Water: & $0.410 \mathrm{lh} / \mathrm{s}$ & Water: & $0.430 \mathrm{lo} / \mathrm{s}$ \\
\hline
\end{tabular}




\begin{tabular}{|c|c|c|c|}
\hline Run: & No. 43 & Run: & No. 44 \\
\hline Regime: & annular mist, 60 psia & Regime: & wave motion, 60 psia \\
\hline Date: & Feb. 21, 1979 & Date: & Feb. 21,1979 \\
\hline$\underline{I}_{s} E_{-}:$ & $80.8 \mathrm{~mm}$, horizontal & $\underline{\text { I.D.: }}$ & $80.8 \mathrm{~mm}$, horizontal \\
\hline Steam: & $0.770 \mathrm{lb} / \mathrm{s}$ & Steam: & $0.100 \mathrm{lb} / \mathrm{s}$ \\
\hline Water: & $1.4401 \mathrm{~b} / \mathrm{s}$ & Water: & $0.333 \mathrm{lb} / \mathrm{s}$ \\
\hline Run: & №. 45 & Run: & No. 46 \\
\hline Regime: & annular mist, 90 psia & Regime: & annular mist, 90 psia \\
\hline Date: & Feb. 22,1979 & Date: & Feb. 22, 1979 \\
\hline I.D.: & $80.8 \mathrm{~mm}$, horizontal & $\underline{\text { I.n.: }}$ & $80.8 \mathrm{~mm}$, horizontal \\
\hline Steam: & $0.560 \mathrm{lb} / \mathrm{s}$ & Steam: & $1.560 \mathrm{lb} / \mathrm{s}$ \\
\hline Water: & $0.6201 \mathrm{~b} / \mathrm{s}$ & Water: & $0.470 \mathrm{lb} / \mathrm{s}$ \\
\hline Run: & No. 47 & Run: & No. 48 \\
\hline Regime: & superheated steam, 90 psia & Regime: & annular mist, 90 psia \\
\hline Date: & Feb. 22, 1979 & Date: & Feb. 22, 1979 \\
\hline I.D.: & $80.8 \mathrm{~mm}$, hor izontal & I.D.: & $80.8 \mathrm{~mm}$, hor izontal \\
\hline Steam: & $1.070 \mathrm{lb} / \mathrm{s}$ & Steam: & $1.360 \mathrm{lb} / \mathrm{s}$ \\
\hline Water: & 0 & Water: & 0 \\
\hline
\end{tabular}

Video Data Tape No. 4

\begin{tabular}{|c|c|c|c|}
\hline Run: & №. 57 & Run: & №. 58 \\
\hline Regime: & slug flow, 60 psia & Regime: & annular mist, 60 psia \\
\hline Date: & Feb. 23, 1979 & Date: & Feb. 23, 1979 \\
\hline I.D.: & $80.8 \mathrm{~mm}$, hor izontal & $\underline{I . D_{.}:}$ & $80.8 \mathrm{~mm}$, horizontal \\
\hline Steam: & $0.160 \mathrm{lb} / \mathrm{s}$ & Steam: & $1.270 \mathrm{lb} / \mathrm{s}$ \\
\hline Water: & $9.4701 \mathrm{~b} / \mathrm{s}$ & Water: & $0.460 \mathrm{lb} / \mathrm{s}$ \\
\hline
\end{tabular}




\begin{tabular}{|c|c|c|c|}
\hline Run: & №. 59 & Ruñ: & No. 60 \\
\hline Regime: & slug flow, 90 psia & Regime: & wave motion, 90 psia \\
\hline Date: & Feb. 23, 1979 & Date: & Feb. 23,1979 \\
\hline I.D.: & $80.8 \mathrm{~mm}$, horizontal & I. D.: & $80.8 \mathrm{~mm}$, horizontal \\
\hline Steam: & $0.340 \mathrm{lb} / \mathrm{s}$ & Steam: & $1.140 \mathrm{lb} / \mathrm{s}$ \\
\hline Water: & $6.100 \mathrm{1b} / \mathrm{s}$ & Water: & $0.920 \mathrm{lb} / \mathrm{s}$ \\
\hline Run: & No. 61 & Fun: & No. 63 \\
\hline Regime: & superheated steam, 60 psia & Regime: & superheated steam, 60 psia \\
\hline Date: & Feb. 23, 1979 & Date: & Feb. 23,1979 \\
\hline I.D.: & $80.8 \mathrm{~mm}$, horizontal & $\underline{I . D_{.}:}$ & $80.8 \mathrm{~mm}$, horizontal \\
\hline Steam: & $1.350 \mathrm{lb} / \mathrm{s}$ & Steam: & $0.220 \mathrm{lb} / \mathrm{s}$ \\
\hline Water: & 0 & Water: & 0 \\
\hline
\end{tabular}

Run: $\quad$ No. 146

Run: $\quad$ No. 147

Regime: slug flow, 60 psia

Regime: annular mist, 60 psia

Date: Mar. 13, 1979

Date: $\quad$ Niar. 13, 1979

I.D.: $\quad 113.0 \mathrm{~mm}$, horizontal

I.D.:

$113.0 \mathrm{~mm}$, horizontal

Steam: $\quad 0.3001 \mathrm{~b} / \mathrm{s}$

Steam: unknown

Water: $\quad 1.800$

Water: unknown

$\begin{array}{llll}\text { Run: } & \text { No. } 158 & \text { Rur: } & \text { No. } 159 \\ \text { Regime: } & \text { annular mist, 60 psia } & \text { Regime: } & \text { annular mist, } 60 \text { psia } \\ \text { Date: } & \text { Mar. 14, 1979 } & \text { Date: } & \text { Mar. 14, 1979 } \\ \text { I.D.: } & 113.0 \mathrm{~mm} \text {, horizontal } & \text { I.D.: } & 113.0 \mathrm{~mm} \text {, horizontal } \\ \text { Steam: } & 1.540 \mathrm{lb} / \mathrm{s} & \text { Steam: } & 2.400 \mathrm{lb} / \mathrm{s} \\ \text { Water: } & 2.880 & \text { Water: } & 0.710\end{array}$




\begin{tabular}{|c|c|c|c|}
\hline Run: & No. 160 & Run: & No. 161 \\
\hline Regime: & wave motion, 60 psia & Regime: & slug flow, 60 psia \\
\hline Date: & Mar. 14, 1979 & Date: & Mar. 14, 1979 \\
\hline$\underline{I . D_{.}:}$ & $113.0 \mathrm{~mm}$, hor izontal & I.D.: & $113.0 \mathrm{~mm}$, horizontal \\
\hline Steam: & $1.190 \mathrm{lb} / \mathrm{s}$ & Steam: & $0.300 \mathrm{lb} / \mathrm{s}$ \\
\hline Water: & 0.630 & Water: & 1.820 \\
\hline Run: & No. 162 & Run: & No. 164 \\
\hline Reqime: & annular mist, 30 psia & Regime: & slug flow, 30 psia \\
\hline Date: & Mar. 14, 1979 & Date: & Mar. 14, 1979 \\
\hline I.D.: & $113.0 \mathrm{~mm}$, horizontal & I.D.: & $113.0 \mathrm{~mm}$, horizontal \\
\hline Steam: & $1.550 \mathrm{lb} / \mathrm{s}$ & Steam: & $0.230 \mathrm{lb} / \mathrm{s}$ \\
\hline Water: & 1.280 & Water: & 1.280 \\
\hline
\end{tabular}

$\begin{array}{ll}\text { Run: } & \text { No. } 165 \\ \text { Regime: } & \text { wave motion, } 30 \mathrm{psia} \\ \text { Date: } & \text { Mar. } 14,1979 \\ \text { I.D.: } & 113.0 \mathrm{~mm}, \text { horizontal } \\ \text { Steam: } & 0.095 \mathrm{lb} / \mathrm{s} \\ \text { Water: } & 1.260\end{array}$

\section{Video Data Tape No. 5}

This video data tape contains spool-piece test runs No. 204-211 and No. 224. All test runs were of the vertically positioned 80.8-mm spool piece. Test dates were March 27 and 28, 1979. Spool tests No. 204 through 211 were made at ambient temperatures and pressure. Several later tests were made at $145^{\circ} \mathrm{C}$ and 60 psia. 